\title{
Influence of Mining on Physico-Chemical Characteristics of Soils in the Iron Ore Belt of Bolani, Odisha, India
}

\author{
Dr.B.K.Ratha \\ PG Department of Geology, \\ Utkal University,Bhubaneswar \\ Odisha, India
}

\author{
SR Barick \\ PG Department of Geology, \\ Utkal University,Bhubaneswar \\ Odisha, India
}

\begin{abstract}
Soil degradation takes place due to mining and industrial activities. The natural properties of soils which are capable of sustaining plants are altered due to such anthropogenic activities. Assessment of soil properties is necessary in these areas. Bolani and its adjoining areas are well known for iron ore mining and mineral based industries. Soil samples were collected from these areas to determine their physic-chemical properties. Analysis of soil samples was carried out following standard procedures. It is observed that majority of the soil samples of the study area show silt-loam texture, poor sorting, negative skewness and platykurtic nature. The bulk and particle densities of the soils vary from 1.1 to $2.5 \mathrm{~g} / \mathrm{cm}^{3}$ and 2.267 to $4.578 \mathrm{~g} / \mathrm{cm}^{3}$ respectively with variable porosities of 32.1 to $62.1 \%$. The organic matter content and cation exchange capacity(CEC) of soils are low varying from 0.03 to $2.86 \%$ and 2.6 to $7.8 \mathrm{meq} / 100 \mathrm{~g}$ respectively. Observations reveal mixing of wash outs from mining and mineral processing units affecting soil properties.
\end{abstract}

Key words:Soil texture, soil size, particle density, cation exchange capacity, Iron ore belt, Bolani.

\section{INTRODUCTION}

Soil is a vital link in the hydrological cycle. Soil holds the nutrient for plants. The size of the particles influences the characteristics of the soil. Organic matter makes the soil spongy so that the roots of plants are able to hold the required water and nutrients.Soil is formed by the weathering of rocks. The first layer of the soil known as top soil is a mixture of organic material and minerals (Korte et $\mathrm{al}, 1976)$. The formation of top soil is a slow process and may take about 1000 years. Mining and processing minerals are the most environmentally damaging of all human activities (Miller, 1994).Bolani and Barbil are well known for mining and industrial activities. Mining, generally involves excavation, drilling, blasting, loading and transport of ores. Also, beneficiation of ores are carried out at mining site to meet the demand for specific metallurgical plants. mining and industrial activity in a region can greatly obliterate this natural balance by accelerated 
accumulation of undesirable trace metals and major cations in soils, rendering it unsuitable for plant growth ((Melegy, 2005). Several investigations carried out on soils (Ansari et al. 2000; Hren et al., 2001; McGregor et al., 1998; Lin and Herbert, 1997; Bullock and Bell, 1997; Clark et al., 2001; and Gabler and Schneider, 2000) reveal that the soils and the sediments of the nearby mining area are severely contaminated by mine wastes in most part of the world. Studies carried out by Harber and Froth(2001) and Mahapatra (2000) reveal that sites where iron and steel were manufactured or processed are likely to contaminate surrounding soils. Studies carried out by Juwarkar and Malhotra (1994) correlate poor nutrient holding capacity with manganese mine spoil dumps Maharastra. Hence, determination and monitoring of physico-chemical characteristics of soils of mining and industrial area are necessary to know the changes in the soil properties.

\section{Geological Setting}

The present study area (Fig.1)

lies in Bolani and Barbil of Keonjhar district, Orissa. between $22^{\circ} 3^{\prime} \mathrm{N}$ to $22^{\circ}$ $8^{\prime} \mathrm{N}$ latitude and $85^{\circ} 18^{\prime} \mathrm{E}$ to $85^{\circ} 25^{\prime} \mathrm{E}$ longitudes falling in the Survey of India toposheet No.73F/8. The climate of the district is tropical to sub-tropical with hot summer, high and well distributed rainfall during the monsoon. The areas are known for their iron and manganese ore deposits. Rocks of the area belong to Iron Ore Group (IOG) comprising mainly Banded Iron Formation (BIF) and associated volcano-sedimentary rocks (Acharya,1984). The Banded Iron Formation more or less circumscribes the Singhbhum granite batholith. BIF occurrences in Joda-Barbil-Noamundi, Gorumahisani, Daitari are rich in iron ore deposits. The BIF occurs in the form of iron minerals and silica bands. The iron-rich bands mainly comprise hematite, martite, magnetite, specularite and goethite, where as silica-rich bands consist of quartz or jasper (Chakraborty and Majumdar, 1986 and 2002). The other rock types of the area include shale (with / without Mn-ores), phyllite, tuff, dolomite, mafic lavas. Manganese deposits comprise secondary manganese minerals such as cryptomelane, pyrolusite, lithiophorite and manganite (Mohapatra et al., 2002). The dolomites of the area are associated with shales.

\section{MATERIALS AND METHODS}

For soil samples, $1 \mathrm{~kg}$ representative samples were taken in clean polyethylene bags. With proper numbering the sample packets were sealed. The samples were taken from different areas both near and away from 
mining sites. The samples were collected during 2012-2014.

For determining bulk density about $100 \mathrm{~g}$ of soil sample (<200mesh) was dried in an oven at $105^{\circ} \mathrm{C}$ until a constant weight is attained. The sample was transferred to a measuring cylinder and its volume was recorded. The weight of the sample was then determined. The bulk density was calculated from weight of the soil and volume of the soil. Specific gravity was determined by a specific gravity bottle. Porosity of soil is the fraction of soil space not occupied by soil particles. It is calculated from the values of bulk density and specific gravity.

Organic carbon of soil was found out by oxidizing the samples in $\mathrm{K}_{2} \mathrm{Cr}_{2} \mathrm{O}_{7}$ solution in acidic medium. Then the sample was filtered and the solution was titrated against standard ferrous ammonium sulphate with diphenylamine indicator to a brilliant green end point. Organic matter was calculated from organic carbon. For determination of soil moisture a known weight of a sample of moist soil is dried in an oven at a temperature of $100^{\circ}$ to $110^{\circ} \mathrm{C}$ and weighed again. The moisture lost by heating represents the soil moisture content of the sample.

For soil texture soil samples were airdried at room temperature. A known amount of representative sample was mixed in sodium hexametaphosphate solution $(0.25 \mathrm{~N})$ and kept overnight with intermittent stirring in order to disaggregate the flocculated clay particles. Soluble salts were removed by washing with distilled water. The finer fraction $(<0.063 \mathrm{~mm})$ was separated by wet sieving using standard sieves. The materials coarser then $0.063 \mathrm{~mm}$ $(63 \mu \mathrm{m})$, which retained on the sieve was dried in an air oven at $100^{\circ} \mathrm{C}$, cooled and weighed. This corresponds to the weight fraction of the soil. The suspension thus separated out was allowed to stand for a few hours, decanted and dried at $100^{\circ} \mathrm{C}$. The weight of the fraction size below 63 microns thus obtained represents the percentage of silt and clay present in the sample. The size analysis below 63micron particles was carried out by using a Malvern Particle Size Analyser (Model 3600). The size data was then 
plotted in a standard triangular diagram, which gives the soil texture of the area.

Statistical parameters of size data was obtained by plotting the size data in a probability graph paper and converting the size data in $\mathrm{mm}$ into $\phi$ scale. The cation-exchange capacity (CEC) was determined by measuring the milliequivalents of sodium adsorbed per $100 \mathrm{~g}$ of soil upon treating a sample with an excess of normal sodium acetate solution of $\mathrm{pH}$ 8.2.

\section{RESULTS AND DISCUSSION}

\subsection{Soil texture and structure}

Soil texture play an important role in the moisture content of soil over which growth of vegetation depends. In mine spoil dumps generally oversize ( $>2 \mathrm{~mm}$ ) materials are present (60-68\%). Thus, mine spoil dumps are dominated by gravels and sand fraction whereas natural soils are dominated by silt and clay. Soil contamination due to washout materials from overburden dumps alters the natural proportion of sand, silt and clay by which the moisture content is highly reduced and this affects the growth of vegetation.

The soil textures found in Bolani and Barbil area are silt-loam, loam, sandyclay-loam, sandy-loam, loamy-sand and silt-clay-loam. The textures of different locations are shown in Fig.3 . A large number of samples (9 numbers) fall in the silt-loam field of triangular diagram indicating the silt-loam texture is the major texture of the study area.

The silt percentage of soils of Bolani varies from 14.7 to $67.5 \%$. The sand percentage of soils varies from 7.2 to $74.9 \%$. Clay percentage of soils varies from 3.6 to $27.6 \%$. In soils of Barbil area sand percentage varies from 8.9 to $72.8 \%$, silt percentage varies from 15.6 to $62.8 \%$ and clay percentage varies from 11.6 to $31.6 \%$. The details of size analysis are given in Table5.1.A.

There is not much variation in the textures of both Bolani and Barbil area. Samples near to mine area are dominated by sand and silt fractions compared to samples away from mine area. This may be due to overburden 
mixing of mine wastes with soils of the area.

Soil structure refers to organization and clumping of soil particles. For growth of plants good development of soil structure or soil aggregates are necessary. It has been observed that the soils near to mine area do not show significant development of soil structure and are usually loose mixture of sand, silt and clay dominated by sand and silt fractions.

Study of size distribution and their interpretation is done following the interpretation table of Prothero and Schwab (1996).

21 samples of both Bolani and Barbil from different locations are subjected to size analysis through standard sieves and particle analyzer, and the size data are plotted in a probability paper after converting the size data in millimeter to $\varnothing$ values. Majority of samples of study area are very poorly sorted, show negative skewness and platykurtic.

\subsection{Bulk Density, Particle Density and}

\section{Porosity}

The bulk density is an important parameter for determining the fertility status of soils. It has been reported that plant roots were unable to penetrate a loamy soil when the bulk density exceeds the value of $1.8 \mathrm{~g} / \mathrm{cm}^{3}$ and drainage difficulties can be anticipated if bulk density exceeds $1.7 \mathrm{~g} / \mathrm{cm}^{3}$ (Agriculture Handbook 60, 1960). The bulk density of soils of Bolani and Barbil area varies from 1.1 to $2.5 \mathrm{~g} / \mathrm{cm}^{3}$. Particle density depends on the chemical composition and crystal structure of the mineral particles. The particle density of soils of Bolani and Barbil varies from 2.267 to $4.578 \mathrm{~g} / \mathrm{cm}^{3}$.

Porosity influences the infiltration and percolation of water and is useful in designing the irrigation and drainage management system. The porosity of soils of study area varies from 32.1 to $62.1 \%$.

\subsection{Soil moisture}

Mixing of mine spoils in the surrounding soils reduces the moisture content of soil. Adequate moisture content is a pre-requisite for sustenance of vegetation on soils. Minimum moisture content $8 \%$ is required for growth of vegetation on soils. The moisture content of Bolani and Barbil area are low and their values range from 1.8 to $13.33 \%$. It is generally observed that oversize materials $(>2 \mathrm{~mm})$ are plenty 
(60-68\%) in overburden dumps. Hence, due to predominant gravel fraction (>2 $\mathrm{mm}$ ) the moisture retention capacity of mine spoils are observed to be grossly inadequate. Hence, mixing of mine spoils with the surrounding area is likely to affect the moisture retention capacity of the soils, thereby, hindering growth of vegetation (Maiti et al., 2001). Vegetation on soils with insufficient moisture contents suffers severe moisture stress in dry season.

\subsection{Organic matter}

Organic matter controls the nutrient availability to plants. The organic matter content of soils of Bolani and Barbil are low and varies from $0.03 \%$ to $2.86 \%$. The low organic matter content is also reflected in their characteristic reddish yellow colour.

\subsection{Cation Exchange Capacity (CEC)}

The cation exchange capacity (CEC) is a measure of the number of ions that can be adsorbed in an exchangeable fashion on the negative charge sites of the soil. The amount of clay in relation to amount of sand and silt influences the CEC of the soil. In general, higher the clay content higher the CEC and lower the mobility of these elements. The CEC of soils of Bolani and Barbil varies from
$2.6 \mathrm{meq} / 100 \mathrm{~g}$ to $7.8 \mathrm{meq} / 100 \mathrm{~g}$. Hence, the CEC values are low indicating that the soils are rich in kaolinites and may be contaminated by mine wastes.

\section{CONCLUSION}

Analysis of soil samples for size, texture, bulk density, particle density, porosity, soil moisture, organic matter, cation exchange capacity revealed the alteration of properties of surface soils due to mixing of over burden materials from mine dumps and mineral processing industries into the soil aided by fluvial geomorphic processes during monsoon. Hence, appropriate remedial steps may be taken to prevent contamination of the soils from mining and industrial activities in the region.

\section{References}

Acharya, S. (1984). Stratigraphic and structural evolution of the rocks of iron ore basins in Singhbhum-Orissa iron ore province of India. Ind. Jour. Earth. Sci., CEISM, pp. 19-28.

Agriculture Hand Book (1960). U.S.

Dept. of Agriculture, Chapter-I, No. 60 p. 23.

Ansari, A. A., Singh, I. B. and Toboschall, H. J. (2000). Role of monsoon rain on concentration and dispersion patterns of metal pollutants in sediments and soils of Ganga Plain, India. Environmental Geology, Vol. 39(34), pp. 221-237. 
Bullock, S. E. T. and Bell, F. G. (1997). Some problems associated with past mining at a mine in the Wetbank coal field, South Africa. Environmental Geology, Vol. 33(1) pp. 61-71.

Chakraborty, K. L. and Majumdar, T. (1986). Geological aspects of the BIF of Bihar and Orissa. Jour. Geol. Soc. India, Vol. 28, pp. 109-133.

Chakraborty, K. L. and Majumdar, T. (2002). Some important aspects of the banded iron formation of eastern Indian shield (Jharkhand and Orissa). Ind. Jour. Geol., Vol. 74, Nos. 1-4, pp. 37-47.

Clark, M. W., Walsh, S. R. and Smith, J. V. (2001). The distribution of heavy metals in an abandoned mining area; a case study of Strauss Pit, the Drake mining area, Australia: Implications for the environmental management of mine sites. Environmental Geology, Vol. 40(6), pp. 655-663.

Gabler, H. E. and Schneider, J. (2000). Assessment of heavy metal of flood soils due to mining and mineral processing in the Harz mountains, Germany. Environmental Geology, Vol. 39(7), pp. 774-782.

Harber, A. J. and Froth, R. A. (2001). The contamination of former iron and steel work sites. Environmental Geology, Vol. 40(3), pp. 324-330.

Hren, M. T., Chamberlain, C. P. and Magilliganm, F. J. (2001). A combined flood surface and geochemical analysis of metal fluxes in a historical mined region: a case study from the New World Mining District, Montana. Environmental Geology, Vol. 40, pp. 1334-1346.

Juwarkar, A. S. and Malhotra, A. S. (1994). Manganese mine spoil dump reclamation using press mud and biofertilisers - A case study. In: Minerals and Ecology, (Ed.) Banerjee, S. P., Centre of mining and Environment, Indian school of mines, Dhanbad, pp. 95-102.
Korte. N. E., Skopp, J., Fuller, W. H., Niebla, E. E. and Alesii, B. A. (1976). Soil science, Vol. 122, pp. 350-359.

Lin, Z., Herbert (Jr), R. B. (1997). Heavy metal retention in secondary precipitates from a mine rock dump and underlying soil, Dalarna, Sweden. Environmental Geology, Vol. 33(1), pp. 1-12.

Mahapatra, K. C. (2000). Waste management in Visakhapatnam steel plant. In: Environment and waste management, Viswanath, K. (ed.). The Dept. of Geology, Andhra University, pp. 83-91.

McGregor, R. G., Blowes, D. W., Jambor, J. L. and Robertson, W. D. (1998). Mobilization and attenuation of heavy metals within a Nickel mine tailings impoundment near Sudbury, Ontario, Canada. Environmental Geology, Vol. 36(3-4), pp. 305-319.

Mohapatra, B. K., Mishra, P. P., Singh, P. P. and Rajeev (2002). Nature and development of lateritoid type manganese ore bodies in the iron ore group of rocks, Bonai-Keonjhar belt, Orissa. Ind. Jour. Geol., Vol. 74, Nos. 1-4, pp. 145-159.

Harber, A.J. and Forth, R.A. (2001). The contamination of former iron and steel work sites. Environmental Geology, Vol. 40(3), pp.324-330.

Maiti, S.K., Karmakar, N.C. and Sinha, I.N. (2001). Studies on some physical parameters aiding biological reclamation of mine spoil dump. SGAT Bulletin, Vol. 2, No. 1, pp. 22-26.

Melegy A. A. (2005). Environmental geochemistry to soil degradation in Helwan catchment, Egypt, Environmental Geology 48:524-530. 
Miller, G. T. (1994). Living in the environment - principles, connections and solutions. Wadsdworth Publishing Company, Belmont, California, pp. 312-333.

Miller, J.R. (1997). The role of fluvial geomorphic processes in the dispersal of heavy metals from mine sites. Jour. Geochemical Exploration, Vol. 58, pp. 101118.

Prothero, D. R. and Schwab, F. (1999).

Sedimentary Geology: An Introduction to Sedimentary Rocks and Stratigraphy. W.H. Freeman and Company, New York, pp 82-91.

Fig.1.LocationMap

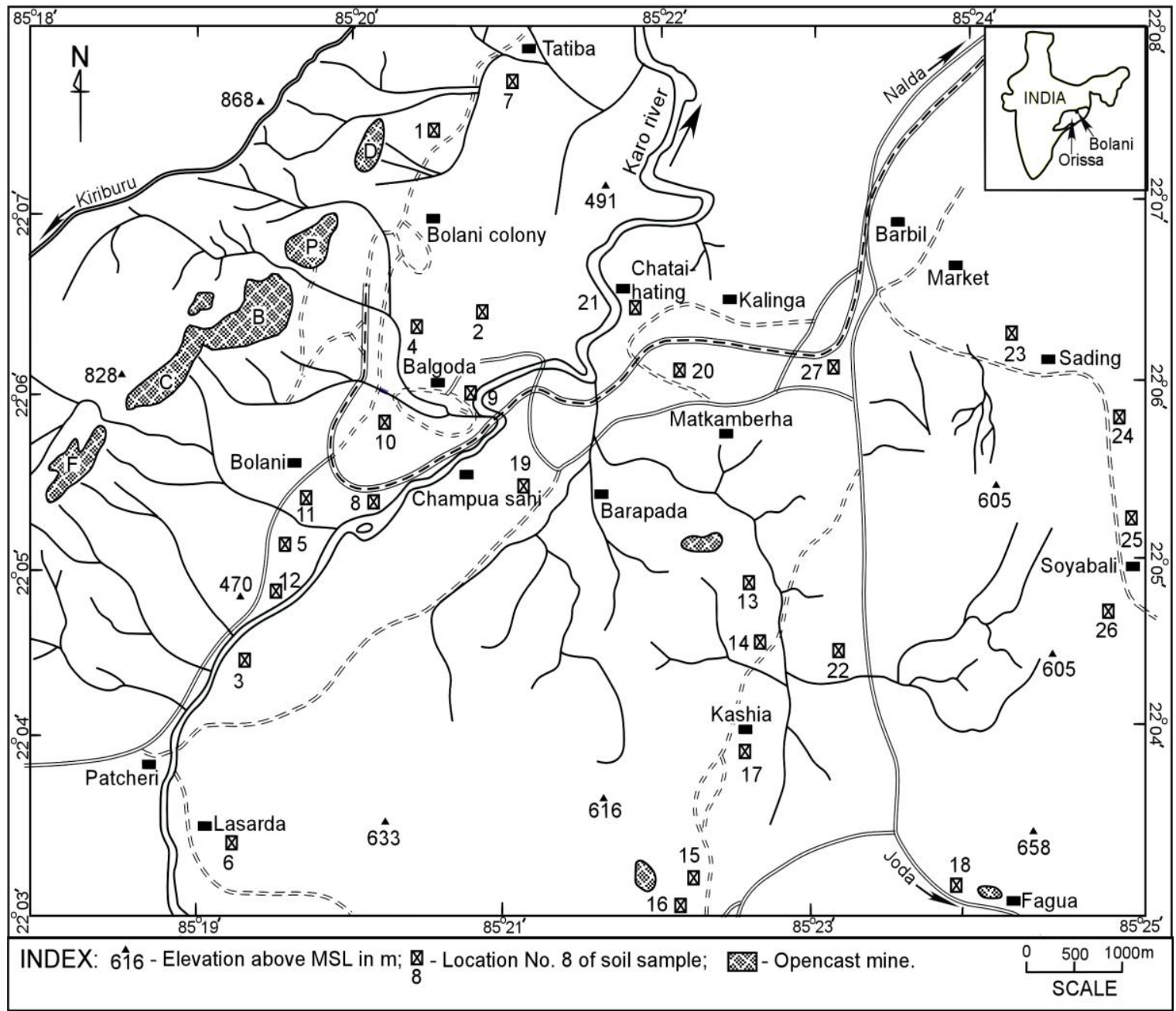




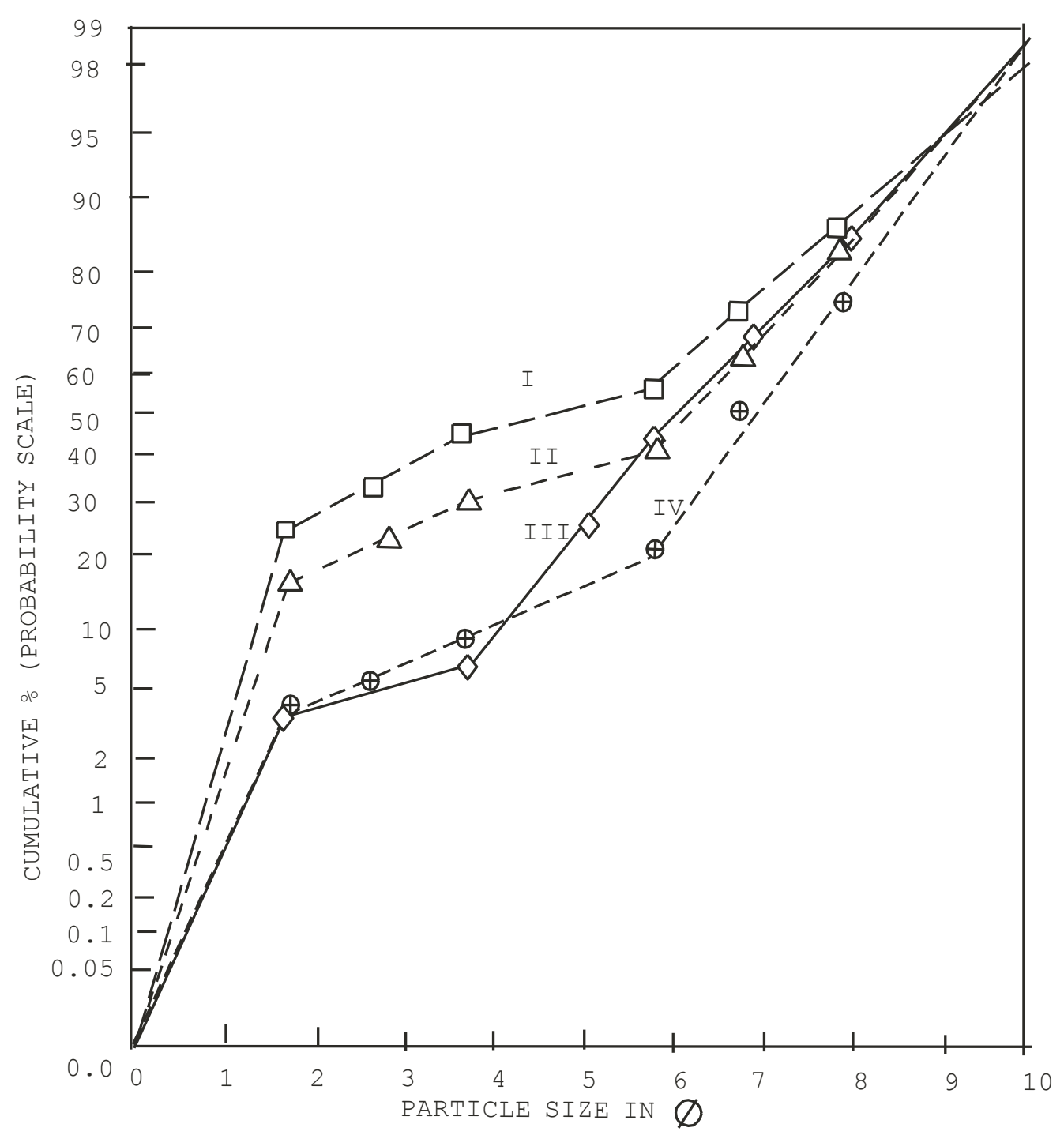

I \& II - SOILS OF BARBIL, III\& IV SOILS OF BOLANI

Fig.2.Graph of Cumulative \% for Soil 


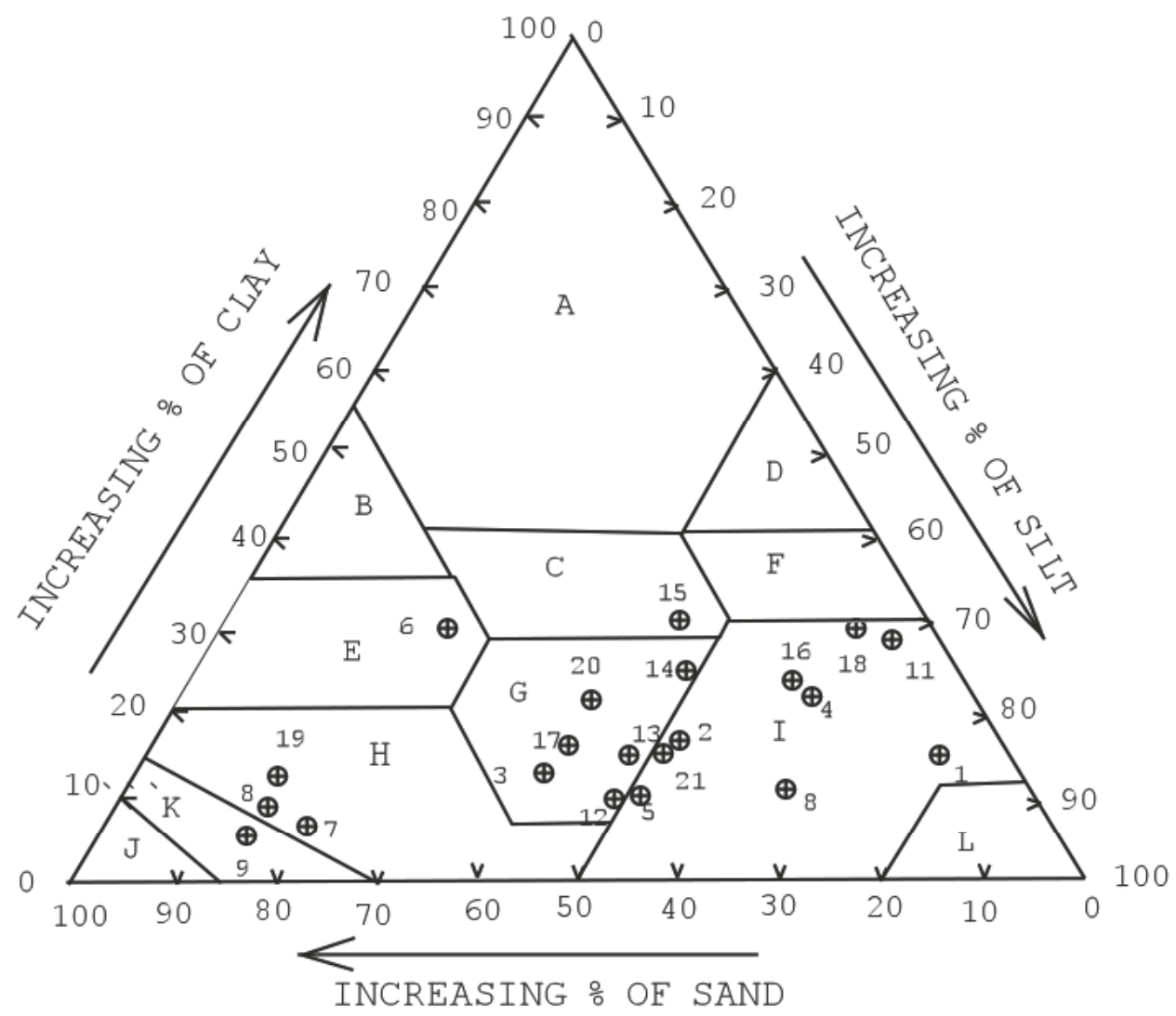

$$
\begin{aligned}
& \text { A-C LAY, B-SANDY CLAY, C-C LAY LOAM, D-SI LTY CLAY } \\
& \text { E-SANDY C LAY LOAM, F-SILTY CLAY LOAM, G-LOAM } \\
& \text { H-SANDY LOAM, I-SI LT LOAM, J-SAND, K-LOAMY SAND } \\
& \text { L-SILT, } \oplus \text { - SAMPLE }
\end{aligned}
$$

Fig.3.Clay,Silt,Sand \% Diagram 
Table.1.Soil Analysis of Study Area in Bolani and Barbil

\begin{tabular}{|c|c|c|c|c|c|c|c|}
\hline Sl. No. & Location & $\begin{array}{c}\text { Organic } \\
\text { matter (\%) }\end{array}$ & $\begin{array}{c}\text { CEC } \\
\mathrm{meq} / 100 \mathrm{~g}\end{array}$ & $\begin{array}{c}\text { Sand } \\
(\%)\end{array}$ & $\begin{array}{l}\text { Silt } \\
(\%)\end{array}$ & $\begin{array}{l}\text { Clay } \\
(\%)\end{array}$ & Texture \\
\hline & BOLANI & & & & & & \\
\hline 1 & Foot hill of D-area & 2.13 & 7.8 & 7.2 & 79.2 & 13.6 & Silt loam \\
\hline 2 & Balgoda Village & 1.47 & 5.7 & 31.1 & 52.2 & 16.7 & Silt loam \\
\hline 3 & Between Bolani and Patcheri Village & 2.11 & 5.4 & 46.4 & 40 & 13.6 & Loam \\
\hline 4 & Front of Panposh quarry & 0.03 & 6.4 & 14.6 & 62.6 & 22.8 & Silt loam \\
\hline 5 & Near Bolani basti & 2.86 & 8.5 & 39.2 & 50.1 & 10.7 & Silt loam \\
\hline 6 & Patcheri Village & 2.34 & 7.5 & 49.5 & 22.9 & 27.6 & Sandy clay loam \\
\hline 7 & Near mine campus & 1.11 & 4.8 & 74.9 & 20.2 & 4.9 & Sandy loam \\
\hline 8 & Tatiba Village & 1.82 & 6.3 & 22.6 & 64 & 13.4 & Silt loam \\
\hline 9 & Near F-Area & 0.44 & 3.8 & 80.9 & 15.5 & 3.6 & Loamy sand \\
\hline 10 & Near F-Area & 0.38 & 2.6 & 73.9 & 14.7 & 11.4 & Sandy loam \\
\hline 11 & Railway over bridge & 2.2 & 6.7 & 8.8 & 67.5 & 23.7 & Silt loam \\
\hline 12 & F-Area & 0.54 & 5.8 & 41.8 & 49.8 & 8.4 & Loam \\
\hline \multirow[t]{2}{*}{13} & Near Intake pump house & 1.87 & 5.6 & 38.3 & 48 & 13.7 & Loam \\
\hline & BARBIL & & & & & & \\
\hline 14 & Near Barpada quarry & 0.66 & 6.3 & 26.6 & 48.6 & 24.8 & Silt loam \\
\hline 15 & Near Barpada quarry & 0.78 & 6.6 & 23.3 & 45.1 & 31.6 & Clay loam \\
\hline 16 & Near Kashia school & 2.12 & 7.2 & 18.7 & 59.7 & 21.6 & Silt loam \\
\hline 17 & Near Fagua Mn dump & 0.86 & 5.4 & 44 & 41.8 & 14.2 & Loam \\
\hline 18 & Near Bhadrasahi & 2.43 & 7.4 & 8.9 & 62.8 & 28.3 & Silt clay loam \\
\hline 19 & Near Sading Village & 1.77 & 6.3 & 72.8 & 15.6 & 11.6 & Sandy loam \\
\hline 20 & Near Kalinga tail water pond & 0.64 & 6.8 & 36 & 39.4 & 24.6 & Loam \\
\hline 21 & Near Champuasahi & 0.44 & 5.6 & 32.8 & 51.9 & 15.3 & Silt loam \\
\hline
\end{tabular}

